\title{
Modeling of the Groundwater Flow and Saltwater Intrusion in the Coastal Aquifer of Fum Al Wad, Province of Laayoun, Morocco
}

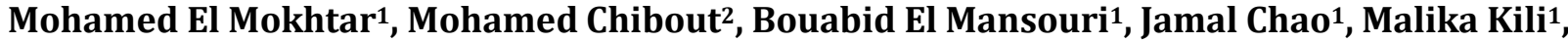 \\ Sidi Mokhtar El Kanti ${ }^{1}$
}

${ }^{1}$ Geosciences Laboratory of Natural Resources, Faculty of Sciences, University Ibn Tofail, Kenitra, Morocco ${ }^{2}$ Geodynamic Laboratory of Natural Resources, Faculty of Sciences, University Dhar Mahraz, Fes, Morocco Email: mohamed.elmokhtar@yahoo.fr,medsaid@yahoo.com,b_elmansouri@yahoo.fr,chao_jamal@yahoo.fr, m_kili@hotmail.com, elkanti01@gmail.com

How to cite this paper: El Mokhtar, M., Chibout, M., El Mansouri, B., Chao, J., Kili, M. and El Kanti, S.M. (2018) Modeling of the Groundwater Flow and Saltwater Intrusion in the Coastal Aquifer of Fum Al Wad, Province of Laayoun, Morocco. International Journal of Geosciences, 9, 71-92. https://doi.org/10.4236/ijg.2018.91005

Received: December 28, 2017

Accepted: January 27, 2018

Published: January 30, 2018

Copyright (C) 2018 by authors and Scientific Research Publishing Inc. This work is licensed under the Creative Commons Attribution International License (CC BY 4.0).

http://creativecommons.org/licenses/by/4.0/

\section{(c) (i) Open Access}

\begin{abstract}
Saltwater intrusion caused by groundwater over-exploitation from coastal aquifers poses a severe problem in many regions. The Fum Al Wad aquifer is located between Atlantic Ocean in the West and Laayoun in the East. This aquifer covers an area of $250 \mathrm{Km}^{2}$, and represents an essential water resource for Laayoun city and the periphery regions. It is heavily exploited for water supply, agriculture and industry. The freshwater-saltwater interface is affected by groundwater extraction by public supplies, irrigation wells, and domestic wells in the coastal of this aquifer. The position of the interface is controlled by several factors: these include precipitation, recharge rate, dryness, evapotranspiration, hydraulic conductivity and hydraulic head. Landward migration of the interface freshwater-saltwater often results in a significant decrease in the water resources available for coastal communities. The volume pumped by public for irrigation and the domestic usage in 2010-2011 is estimated $2.5 \mathrm{Mm}^{3} /$ year, and in 2015 about $2.91 \mathrm{Mm}^{3} /$ year only for domestic usages. The objectives of this work are to model the groundwater flow and saltwater intrusion in the coastal aquifer of Fum Al Wad, by SEAWAT-2000 program which coupled both the version of MODFLOW-2000 and MT3DMS. They are designed to simulate variable-density groundwater flow and solute transport in three dimensions. The model is calibrated for hydraulic conductivity, specific yield, porosity, and recharge rate as well as dispersivity coefficient. The result of simulation of the hydrodynamic model during the period of 1986-2015 has revealed a piezometric drawdown with $2.3 \mathrm{~m}$ approximately at the level of the pumping zone. Furthermore, this piezometric depression is caused by excessive pumping of the various uses of water and its corresponding that has re-
\end{abstract}


sulted in the migration of the saltwater intrusion into freshwater with $4.3 \mathrm{~km}$ approximately. The simulations result for scenarios 2020 and 2030 of Fum Al Wad aquifer showed a vertical decrease of the piezometric head (about $2.5 \mathrm{~m}$ ) in 2030, but the saltwater intrusion has advanced diagonally to reach $4.7 \mathrm{~km}$ under the freshwater of groundwater of this aquifer.

\section{Keywords}

Fum Al Wad Aquifer, Over-Exploitation, Pumping Wells, Saltwater Intrusion, Piezometric Head, Water-Table

\section{Introduction}

Globally, the saltwater intrusion is manifested particularly in coastal and insular aquifers. They are sensitive to the salinization of the freshwater in natural and anthropogenic-influenced conditions [1].

Salinization of coastal groundwater is driven by factors of the over-exploitation, the climatic situation and the geometry of aquifers. Thus, the interface of transition between freshwater-saltwater develops spatially and temporally based on the development of the urban areas and the increase of the pumping activities and climate change.

The problem of the saltwater intrusion has become the main focus of many researchers. Hence, many works have been published by hydrogeologists, geophysicists and hydrochimistes authors [2] [3] [4]. In this respect, they have conducted many studies to provide suggestive solutions. These specialists have set and worked on many hypotheses and perspectives [5] related to the issue being studied. Other recent activities similar to our saltwater intrusion theme use the same seawat-2000 modeling technique that is integrated into the GMS platform [6] [7] [8] [9]. Lately, the climate change and human intervention have aggravated the situation of saltwater intrusion in the: unconfined coastal aquifers [10], confined aquifers [11] and also in estuaries.

The results of many experiments carried out by some laboratories made it possible to direct the science towards the optimization of the intensive exploitation of the coastal water [12]. The desalination technique encourages the economic aspect and reinforces the optimization and perseverance of the water-table [13].

The piezometric, geophysical, hydrochemical and numerical approaches are certainly the most used to determine the state of coastal groundwater and the degree of their contamination by seawater or oceans water [14].

The numerical modeling of saltwater intrusion determines the space-time evolution of the variable-density-flow by using different simulation codes of the saltwater into the freshwater in the coastal groundwater [15]. It serves as a good management method of groundwater resources. The hydrogeological model represents a decision support system that allows managers to conduct works in the future 
to improve the exploitation of this resource.

The objective of this work then is to realize the hydrodynamic and the solute transport modeling of the groundwater of Fum Al Wad aquifer. It also aims at presenting their methodology and the procedure for constructing complete conceptual and mathematical models. The construction of such models is the ultimate goal of this study. In fact, these models are used as essential tools for the planning and management for sustainable use of groundwater resources. This use of models is based on our belief that the physical reality can be represented by mathematical models, albeit with acceptable approximations.

\section{The Governing Mechanism of the Interface between Freshwater and Saltwater}

The presence of the saltwater into coastal aquifers is governed by factors such as: the geometry of the aquifer and the topography of its impermeable bottom. Other factors can also contribute to the increase of salinity in freshwater as the geographical location of the water resource, the geology of the aquifer, climate and over-exploitation of groundwater.

The phenomenon of saltwater intrusion in coastal aquifers porous has been studied by Ghyben and Herzberg at the end of the 19th century [2]. Saltwater is denser than the freshwater; it is naturally in coastal aquifers to a certain depth (z) depending on the hydraulic load of freshwater (h) [16] (Figure 1).

The freshwater and the saltwater are miscible in all proportions. The flow is a justifiable monophasic aspect of modeling by the dispersion theory [17]. Indeed, these two fluids are in hydrostatic equilibrium in homogeneous and porous environment in a unique aquifer. In addition, these fluids' contact is supposed to

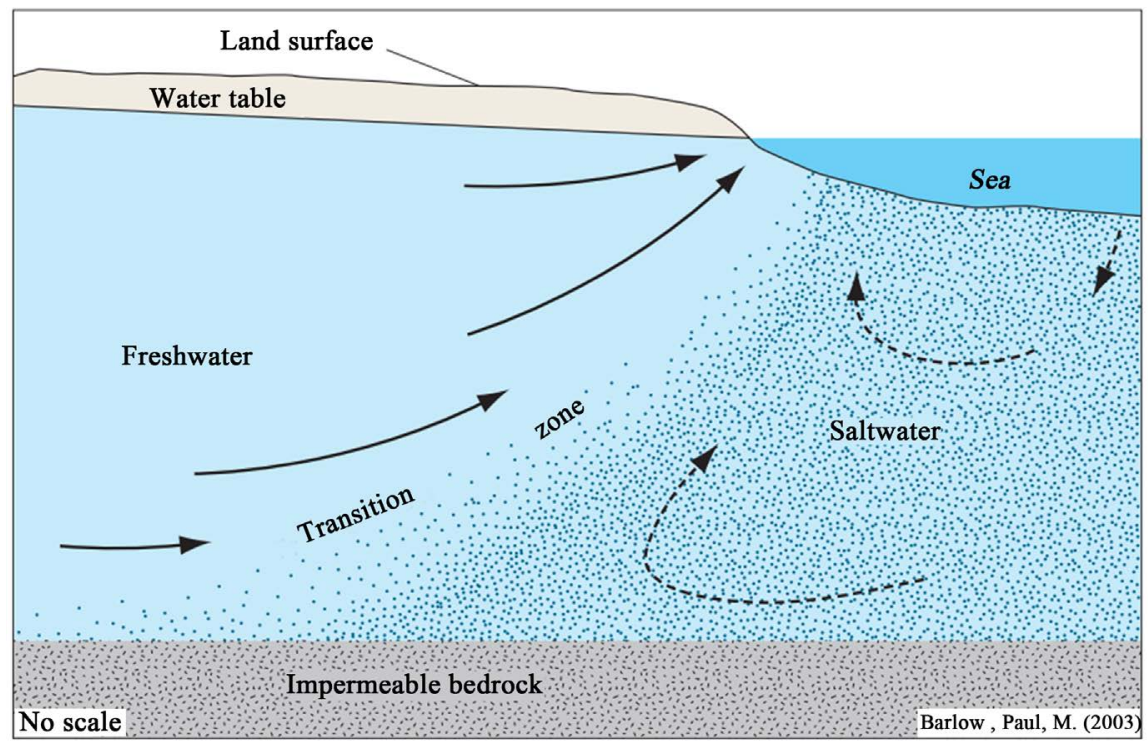

Figure 1. Ground-water flow patterns and the freshwater-saltwater transition zone in an idealized coastal aquifer. A circulation of saltwater from the sea to the transition zone and then back to the sea is induced by mixing of freshwater and saltwater in the transition zone [19]. 
be represented by a net interface [3]. Equal pressures from the freshwater and saltwater are expressed by the following expression of the Ghyben-Herzberg:

$$
z=\frac{\rho_{f}}{\rho_{s}-\rho_{f}} h_{f}
$$

where $(z)$ is the depth of the interface below the level of the sea; $\left(h_{f}\right)$ represents the piezometric head of freshwater; $\rho_{f}$ and $\rho_{s}$ are densities of freshwater and saltwater [18]. These last are equal respectively 1 and $1.025 \mathrm{~kg} / \mathrm{m}^{3}$ [3]. The above equation can be simplified and thus becomes $z=40 h_{f}$

\section{Study Area}

The Fum Al Wad aquifer covers an area which is about $250 \mathrm{~km}^{2}$; it is situated between the East of Laayoun city (the up-rising of impermeable formations of the marls of the Upper Cretaceous), and the West of the Atlantic Ocean. However, the North and the South limits are not exact, but these boundaries were traced from wells' database [20] [21] as in (Figure 2 and Figure 3).

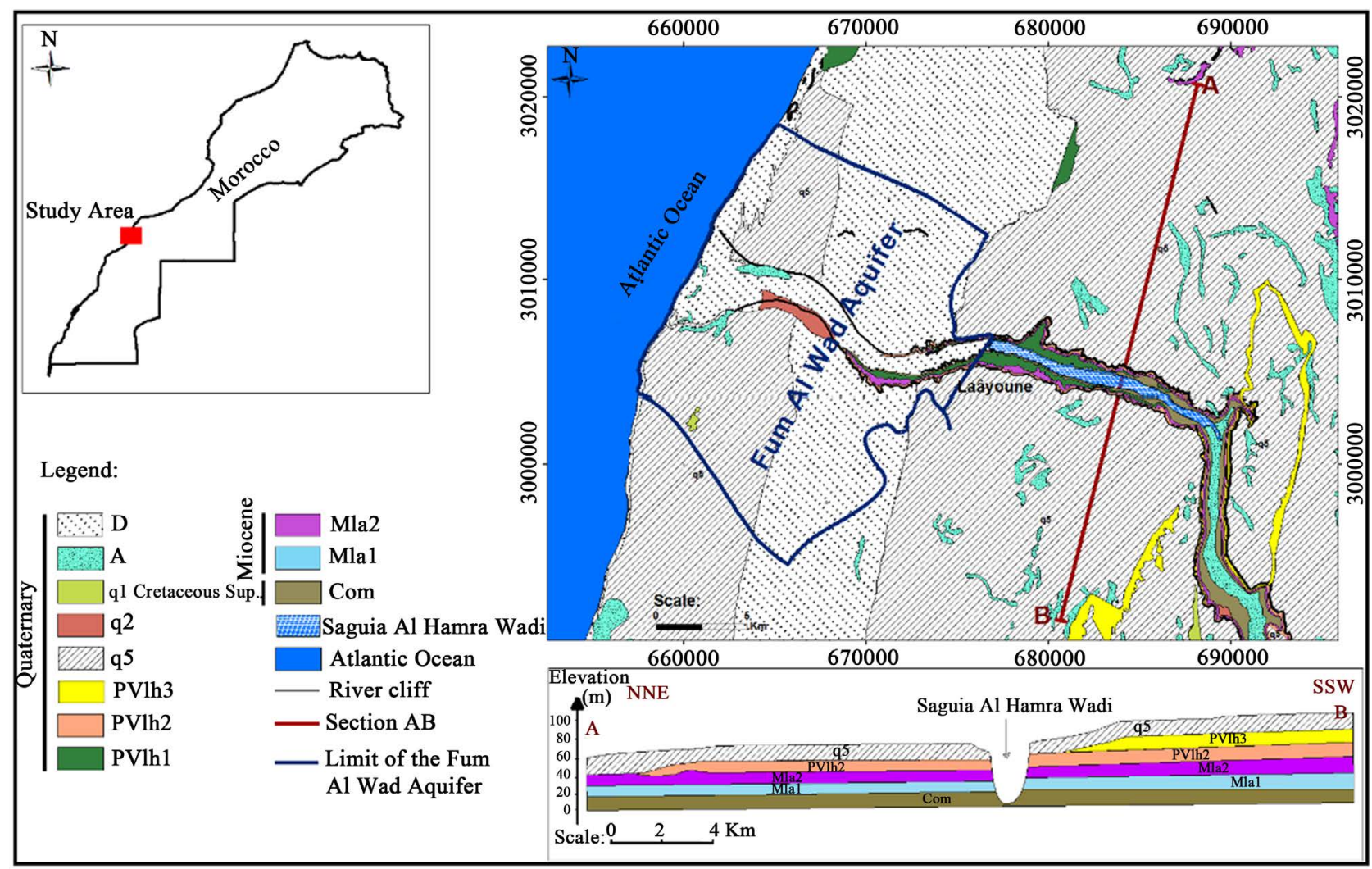

Figure 2. Extract of the geological map of Laayoun in the 1/100,000 scale [34] and the geological section AB oriented NNE - SSW. D: Sandhills; A: Silts and evaporates; q1: Alluvial terrace (named in the Sahara by "recent reg"); q2: Spreading loamy and stony average terrace, "old reg"; Q5: Slab made of carbonated sandstone and conglomerate; PVlh3: Carbonated whitish marl; PVlh2: Clear lumachelle within shells of gastropods, Brachiopods and conglomerate in the base; PVlh1: Redhead lumachelle mainly within oyster shells and gastropods; Mla2: whitish marl sandstone, sometimes with flint; Mla1: Lumachelle, sandy yellowish marls, sandstone, conglomerate, micro alternation of the whitish marls and the yellowish with a bench lumachellique; Com: Grey marl and gypsum. 


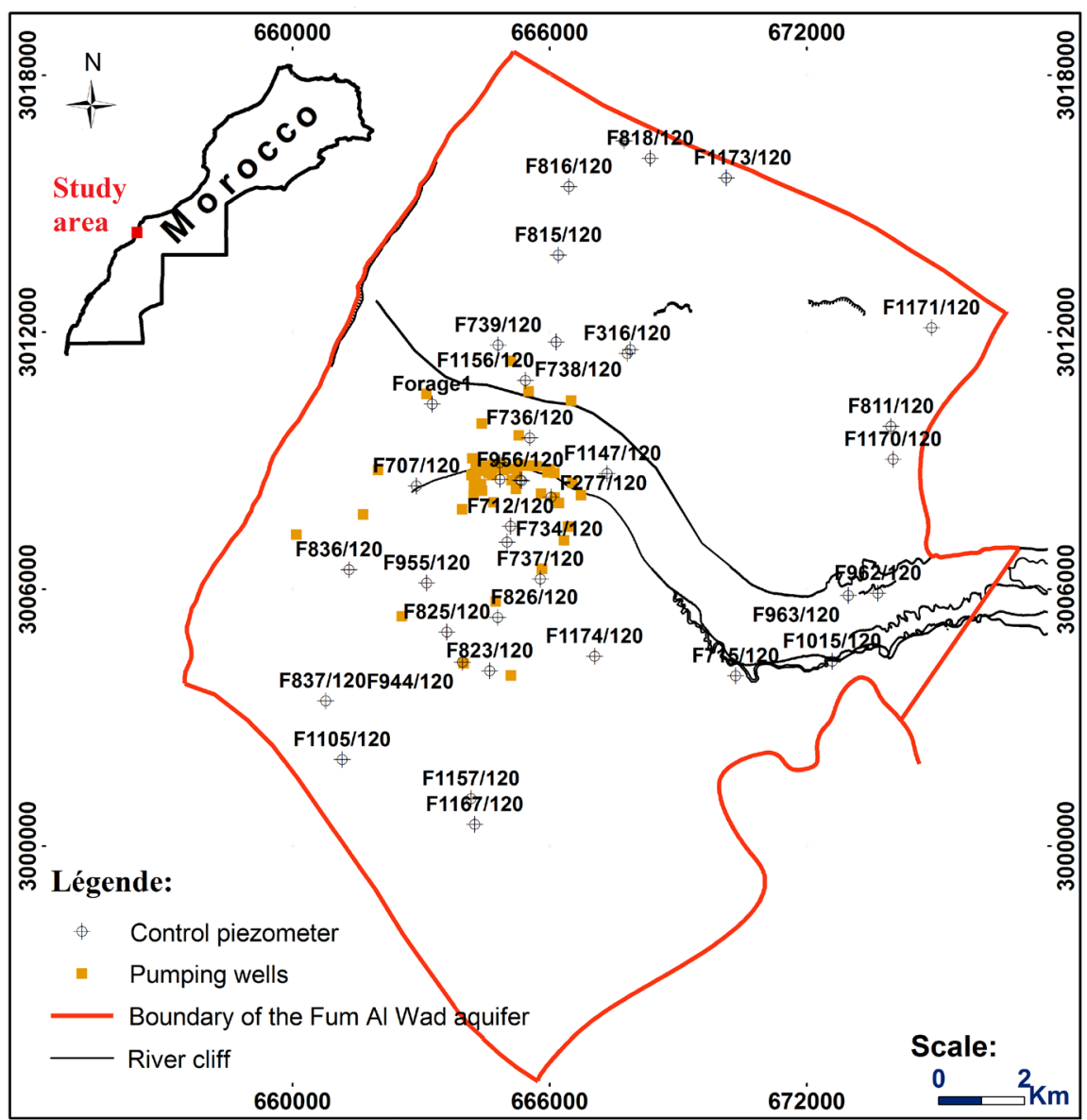

Figure 3. The geographical situation of the used points in calibration models.

It is characterized by a coastal Saharian climate type that is warm in the winter and more or less sunny (cloudiness) with strong winds from the NNE. According to the Hassan I airport weather station of Laayoun city, this climate is softened by the ocean along the coast, while it becomes more and more hostile as one penetrates to the inside of the Saharian lands.

The temperature is somehow high during the year with maximum values in $\mathrm{Au}$ gust about $33.7^{\circ} \mathrm{C}$ except a few wet months. The area of the study receives minimum rainfall rate which do not exceed $10.78 \mathrm{~mm}$ as recorded in the previous month of January. In contrast, the maximum raining years are recorded during the periods 1989-1991 and 1995-1997 with a height of $155 \mathrm{~mm}$ in 1989 as annual rainfall rate.

The Saquia Hamra Wadi (river) represents the main hydrographic element of the region of Laâyoune city. It is characterized by a discontinuous flow depending on the intensity of rainfall and exceptional floods. This river has created a kind of canyon which has distorted the surface floor; it has formed a slight slope towards the Atlantic Ocean. The morphology of this river became less obvious near the coast; this is due to sand-hills that have invaded partially its traces. In the mouth of this river, a form of delta has been created because of the swell of the Atlantic Ocean. The elevation of the natural terrain varies gradually from the 
Atlantic Ocean to Laayoun city, from 0 to $60 \mathrm{~m}$.

The geology of the study area is part of the Meso-Cenozoic basin of Tarfaya-Laayoun-Dakhla which has developed during the Mesozoic and the Cenozoic [22] [23]. Several authors have highlighted a general description of the structural and regional geology of this basin [24]-[33] from the Trias to the recent Quaternary. The main geological formations constituting the aquifer of Fum $\mathrm{Al}$ Wad field are grouped into four families namely: lower sands, dolomitic limestone and sandstone lower, the upper sands and alluvium Plio-Quaternary of the Saquia Al Hamra Wad (Figure 2).

The groundwater of Fum Al Wad aquifer flows into the permeable formations of Plio-Quaternary which rest on an impermeable bottom that is formed by the gray marls of Miocene. It is alluvial phreatic water that is limited to the East by the aquifers of the right bank and the left bank of Laayoun city which are geologically continuous and unrelated hydraulic since their bottom (clays and impermeable marls of the Upper Cretaceous) appear in the middle of the Wadi (Saguia Al Hamra) giving birth to some sources of low flow at the level of Laayoun city.

\section{Methodology}

\subsection{The Mathematical Model of the Variable-Density of Groundwater Flow}

To simulate the variable-density of groundwater flow in water-table, a SEAWAT2000 numerical model was used which coupled the version of MODFLOW 2000 [35] and MT3DMS [36] [37]. This model is designed to simulate three-dimensional of the variable-density of groundwater flow and multispecies transport. The variable density flow (VDF) process uses the familiar and well-established MODFLOW methodology to solve the variable-density of ground water flow equation. The MT3DMS which is part of SEAWAT that is referred to as the Integrated MT3DMS Transport (IMT) process can be used to solve the solute transport equation of the process of saltwater intrusion in coastal aquifers.

Guo and Langevin [38] derive the governing equation for variable-density ground-water flow, in terms of equivalent freshwater head [39], as:

$$
\begin{aligned}
& \frac{\partial}{\partial x}\left[\rho K_{x}\left(\frac{\partial h_{f}}{\partial x}+\frac{\rho_{s}-\rho_{f}}{\rho_{f}} \frac{\partial Z}{\partial x}\right)\right]+\frac{\partial}{\partial y}\left[\rho K_{y}\left(\frac{\partial h_{f}}{\partial y}+\frac{\rho_{s}-\rho_{f}}{\rho_{f}} \frac{\partial Z}{\partial y}\right)\right]+ \\
& \frac{\partial}{\partial z}\left[\rho K_{z}\left(\frac{\partial h_{f}}{\partial z}+\frac{\rho_{s}-\rho_{f}}{\rho_{f}} \frac{\partial Z}{\partial z}\right)\right]=\rho_{s} S_{s} \frac{\partial h_{f}}{\partial t}+\omega_{e} \frac{\partial \rho_{s}}{\partial C} \frac{\partial C}{\partial t}-\rho_{w} W
\end{aligned}
$$

where:

$x, y, z$ are orthogonal coordinate axes, aligned with the principal directions of permeability; $h_{\dot{f}}$ equivalent freshwater head $(\mathrm{m}) ; Z$ is the elevation at the measurement point $(\mathrm{m}) ; \rho_{f}$ : is the density of freshwater $\left(\mathrm{kg} / \mathrm{m}^{3}\right) ; \rho_{s}:$ is the density of saltwater $\left(\mathrm{kg} / \mathrm{m}^{3}\right) ; K_{(x, y, z)}$ : is equivalent freshwater hydraulic conductivity 
$(\mathrm{m} / \mathrm{s}) ; S_{s}$ : is equivalent freshwater specific storage $(1 / \mathrm{m}) ; t$ : time $(\mathrm{s}) ; \omega_{e}$ : is effective porosity (dimensionless); $C$ : is solute concentration $\left(\mathrm{Kg} / \mathrm{m}^{3}\right) ; \rho_{w}$ is fluid density source or sink water. $W$ : is the volumetric flow rate of sources and sinks per unit volume of aquifer $(1 / \mathrm{s})$.

The conversions between $h_{f}$ (freshwater head) and $h_{s}$ (saltwater head) can be made using the following equations [38]:

$$
\begin{aligned}
& h_{f}=\frac{\rho_{s}}{\rho_{f}} h_{s}-\frac{\rho_{s}-\rho_{f}}{\rho_{f}} Z \\
& h_{s}=\frac{\rho_{f}}{\rho_{s}} h_{f}+\frac{\rho_{s}-\rho_{f}}{\rho_{s}} Z
\end{aligned}
$$

For a coupled variable-density flow and solute-transport simulation, a fluid density is assumed to be a function only of solute concentration; the effects of pressure and temperature on fluid density are not considered. A linear equation of state is used to represent fluid density as a function of solute concentration [38]:

$$
\rho_{s}=\rho_{f}+\frac{\partial \rho_{s}}{\partial C} C
$$

where:

$\rho_{f}$ : is the density of freshwater $\left(\mathrm{kg} / \mathrm{m}^{3}\right) ; \rho_{s}$ : is the density of saltwater $\left(\mathrm{kg} / \mathrm{m}^{3}\right)$;

$\mathrm{C}$ : is the solute concentration $\left(\mathrm{Kg} / \mathrm{m}^{3}\right) ; \frac{\partial \rho_{s}}{\partial C}$ : is calculated for the range of expected densities and concentrations. For example, if meters and kilograms are used for the simulation, $\partial \rho / \partial \mathrm{C}$ is set to a value of 0.7143 , which approximately equals the change in fluid density divided by the change in solute concentration for freshwater and seawater.

\subsection{Geographical Situation of the Control Piezometric and Pumping Wells}

The geographical situation of the pumping wells and the control piezometers are illustrated by the following Figure 3. The used coordination system of the all maps of this work is: WGS84, UTM zone 28 Northing.

\subsection{Geometry of the Coastal of Fum Al Wad Aquifer}

The geometry of the aquifer is built using the stratigraphic model which works by the borhole datas of the GMS (Groundwater Modeling System) software [15]. The distribution of these borhole datas is based on the choice of the grids of wells covering the study area (Figure 4). This geometry is retained in the modeling of the saline intrusion phase.

Lithological analysis of the three-dimensional model of the Fum Al Wad aquifer has allowed viewing seven hydrogeological formations which overlap with each other above the impermeable bottom formed by the gray marls of the 


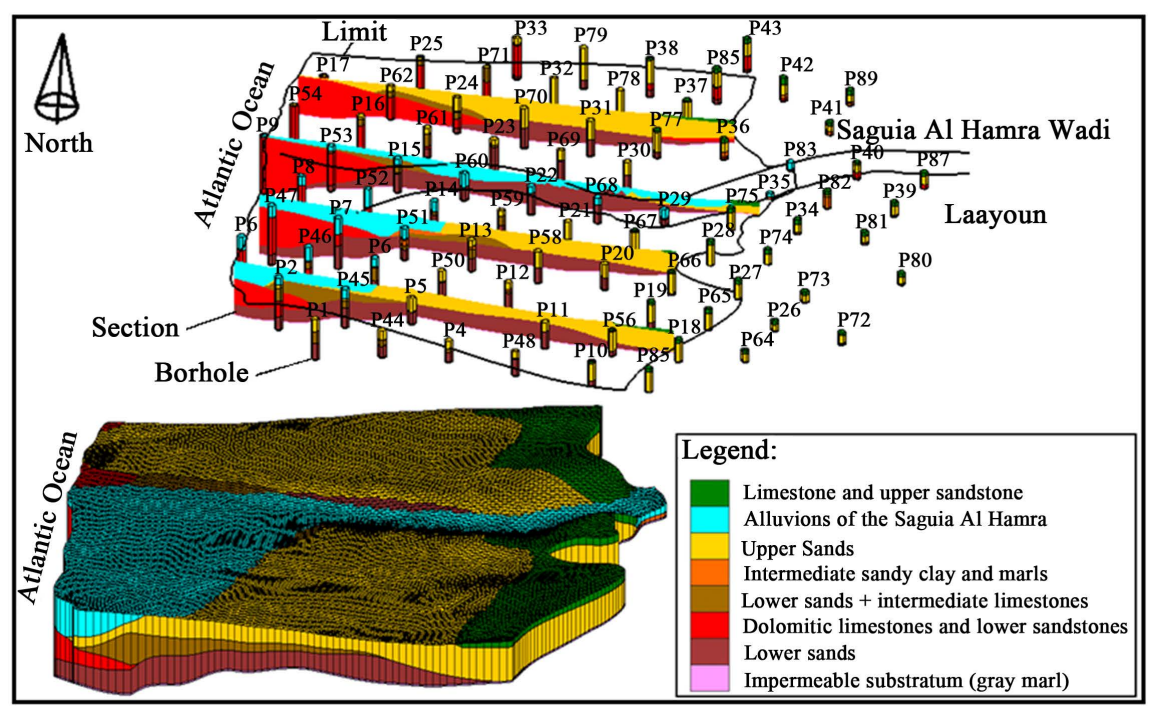

Figure 4. The Geometry and the four lithological cross sections (West-East) of the Fum $\mathrm{Al} \mathrm{Wad}$ aquifer represented in three dimensions.

upper Miocene. These gray marls are deposited on the black marls of the upper Cretaceous. They form a dry ridge downstream from of the Laayoun city [21] [40]. This ridge represents the Eastern boundary of the Fum El Wad water-table.

\subsection{The Discretization and Boundary Conditions of Fum Al Wad Aquifer}

The study area of the Fum Al Wad aquifer is subdivided into eight layers each with a thickness of 20 meters, except the first layer which has a varying size from 22 to 83 meters in Eastern zone (Figure 5).

The model grid consists of 106,476 active cells with an approximate cell dimension of $100 \mathrm{~m} \times 100 \mathrm{~m}$ per each cell in the horizontal plane. The top surface of the model grid is interpolated to the terrain elevation which ranges from 0 to $60 \mathrm{~m}$ and the bottom elevation is plunged downward towards the Atlantic Ocean to reach $-200 \mathrm{~m} / \mathrm{sea}$. The boundary conditions of this aquifer system are highlighted as the following:

- The eastern limit of the Fum Al Wad aquifer is considered as a recharge limit, to take account of the waters coming from the Laayoun aquifer by lateral entry; it is represented by an imposed flow condition;

- The western limit (limit with the Atlantic Ocean) is represented by a condition of imposed potential $(\mathrm{H}=0 \mathrm{~m})$;

- The South and North limits are fictitious and are represented by a null flow.

These three points are clearly illustrated below as in Figure 7.

\section{Results}

\subsection{Piezometry Calculated by the Steady-State Model in 1986}

The mathematical model was established in the piezometric reference-state in 


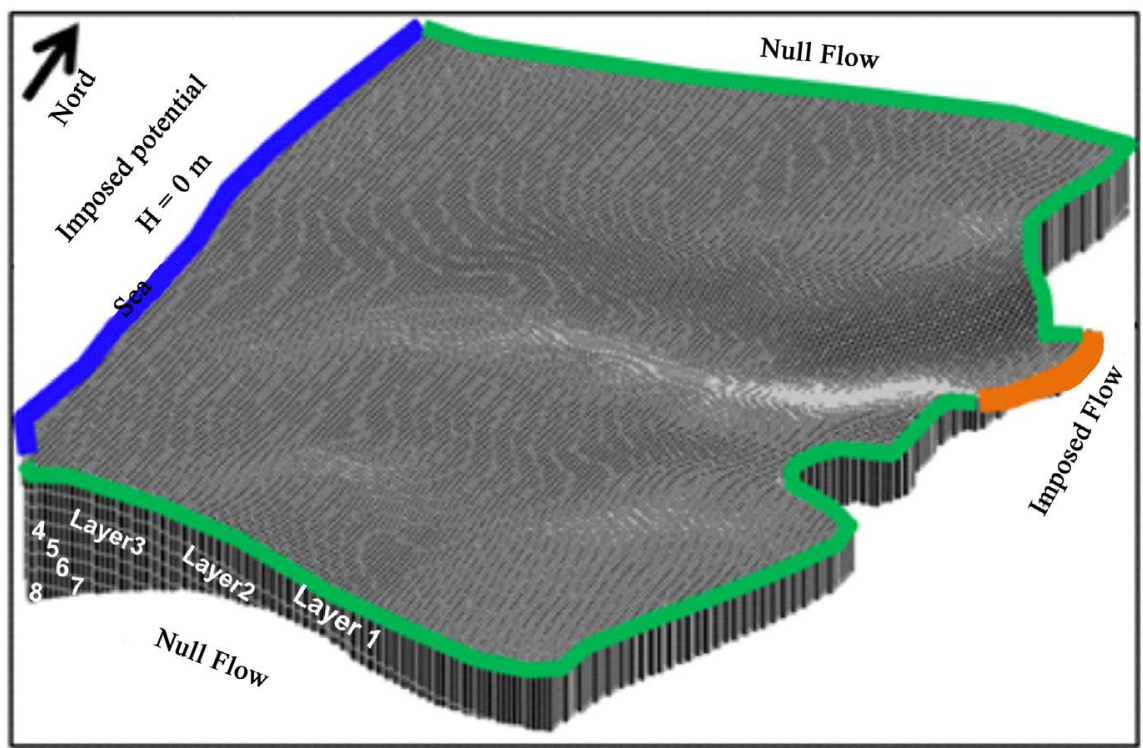

Figure 5. Grid model and boundary conditions of the Fum Al Wad aquifer.

1986. The results of the calibration of the simulated piezometry allowed us to control the hydrodynamism of the aquifer. It has also permitted us to bring out the general balance by deducing terms related to the inflows and outflows of Fum Al Wad water-table. The analysis of the piezometric map (Figure 6) below can give the following information:

- The hydraulic gradient: it is highly manifested in the East and marked a maximum value which is about $0.4 \%$; this is due to the groundwater recharge by the lateral exchange with other water-tables of Laayoun city in the East. However, at the level of the ground-water pumping in the center of Fum $\mathrm{Al}$ Wad aquifer, it became lower and marked a minimum value which is about $0.004 \%$. This indicates that the hydraulic gradient is influenced by the intensive pumping wells by the different cultivators and water supplies.

- The direction of the flow: it is coming from the East towards the West of the Fum Al Wad water-table.

- Piezometry: it varies from 0 meter from the Atlantic Ocean side (West) to 15 meters from Laayoun City side (East).

The permeability map is obtained by creating six (06) areas with hydraulic conductivity values ranging from $2 \times 10^{-4} \mathrm{~m} / \mathrm{s}$ to $9.8 \times 10^{-4} \mathrm{~m} / \mathrm{s}$. The analysis of the sensitivity of the hydraulic conductivity parameter allowed selecting the most sensitive areas in the present model. Thus, the model is sensitive in zones 4, 5 and 6 while it is less sensitive in the zones 1, 2 and 3 as it is illustrated in Figure 7 which also shows the distribution of permeability per area.

\section{Diagram of the steady-state calibration model of 1986}

After several tests of the calibration process in the steady-state regime, the piezometric values simulated by the model and those observed in the land at the level of 40 controlled piezometric points (Figure 3 ) are almost diagonally aligned in Figure 8. 


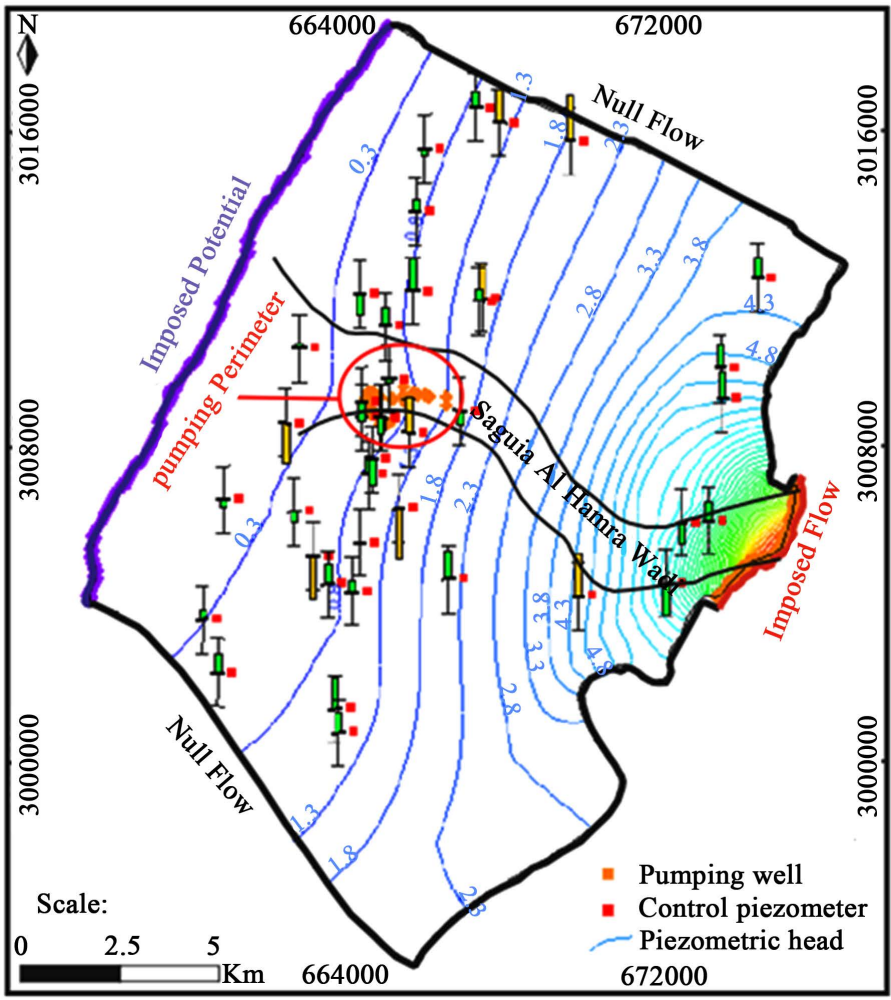

Figure 6. Fum Al Wad piezometry obtained by the calibration of the steady-state regime in 1986.

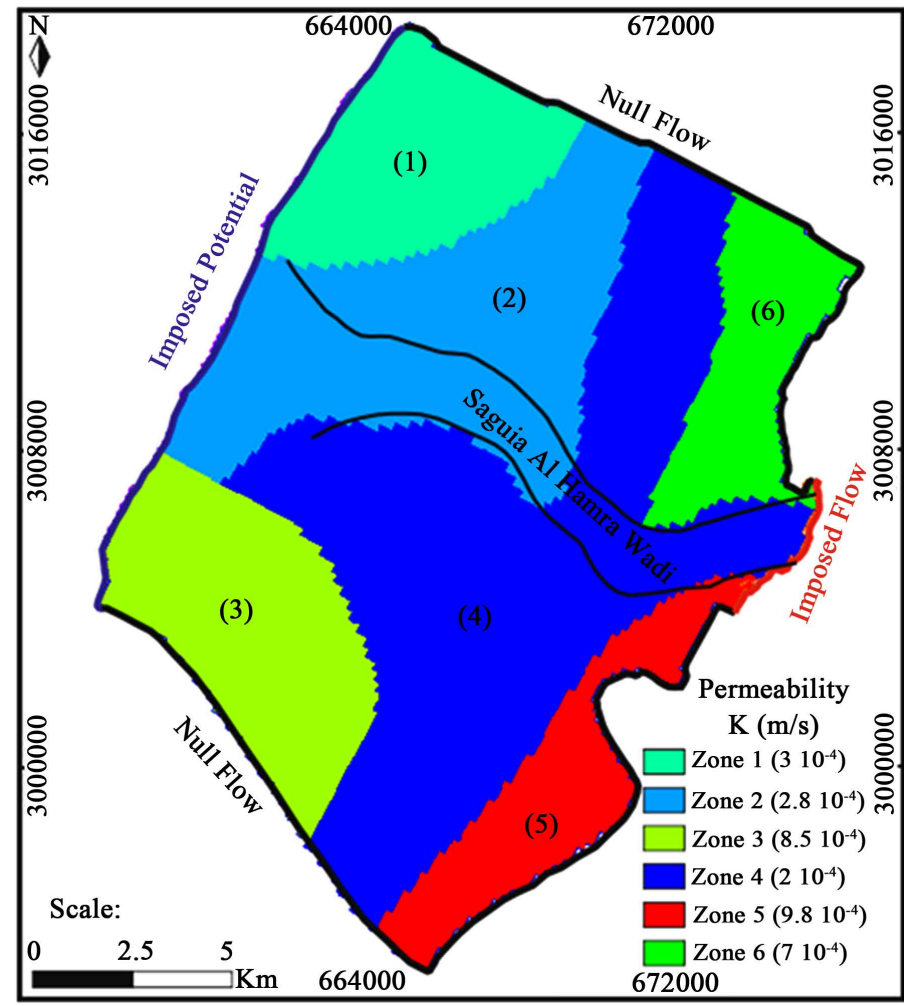

Figure 7. Hydraulic conductivity map of Fum Al Wad aquifer obtained by the calibration the steady-state in 1986. 


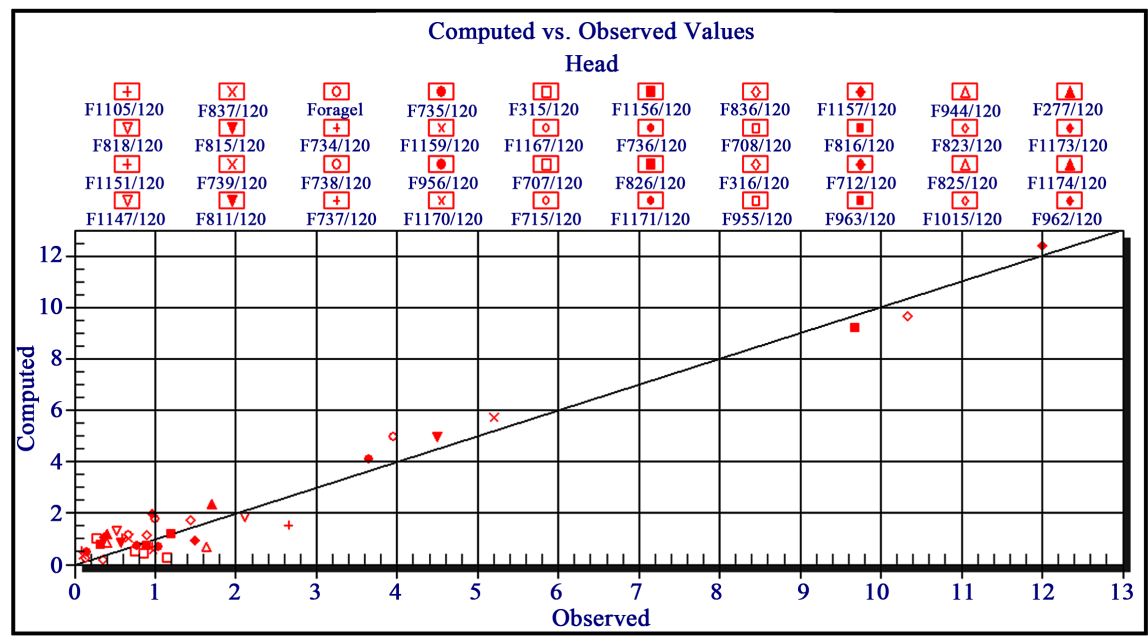

Figure 8. Diagram of the observed and simulated values of the piezometric head obtained by the steady-state model simulation in 1986 .

Furthermore, the simulated values of de permanent model were adjusted with the observed values in which we changed the values of the hydrodynamic parameters (hydraulic conductivity and recharge rates). The following figure represents a perfect approximate match between the observed and the simulated values based on the Groundwater Modeling System (GMS) software program. This calibration diagram shows the observed values and the simulated ones on diagonal line $\left(45^{\circ}\right)$ that was created automatically by the aforementioned program after the phase of calibration. Thus, the simulated and measured values are presented with an acceptable uncertainty that will be retained to calibrate the simulation of transient regime.

\subsection{Piezometry of Fum Al Wad Obtained by the Transient Model in 2015}

\section{1) The piezometric calibration of the transient model}

The transient model of the Fum Al Wad aquifer is constructed annually throughout 29 years, which started from 1986 to 2015 . The verification of the transient calibration is based on six (06) piezometric monitoring piezometers of the water-table. These piezometers are located in the zone center of pumping wells; they have a sufficient piezometric history to control the piezometric evolution of the water-table, and they are influenced by the intensive pumping wells. The simulation of the transient model during 1986-2015 has marked a piezometric depression in 2015 which is about $2.3 \mathrm{~m}$ (Figure 9). This depression is displayed at the zone of the pumping wells in the center of Fum Al Wad water-table and it reflected the deficit flow budget of it. This is due to the overexploitation of this aquifer compared to the 1986 piezometric data.

The calibration of the transient model is performed with six controlling piezometers of Fum Al Wad piezometry since they contain a sufficient history of the piezometric head for the period 1986-2015. Thus, we have used these 


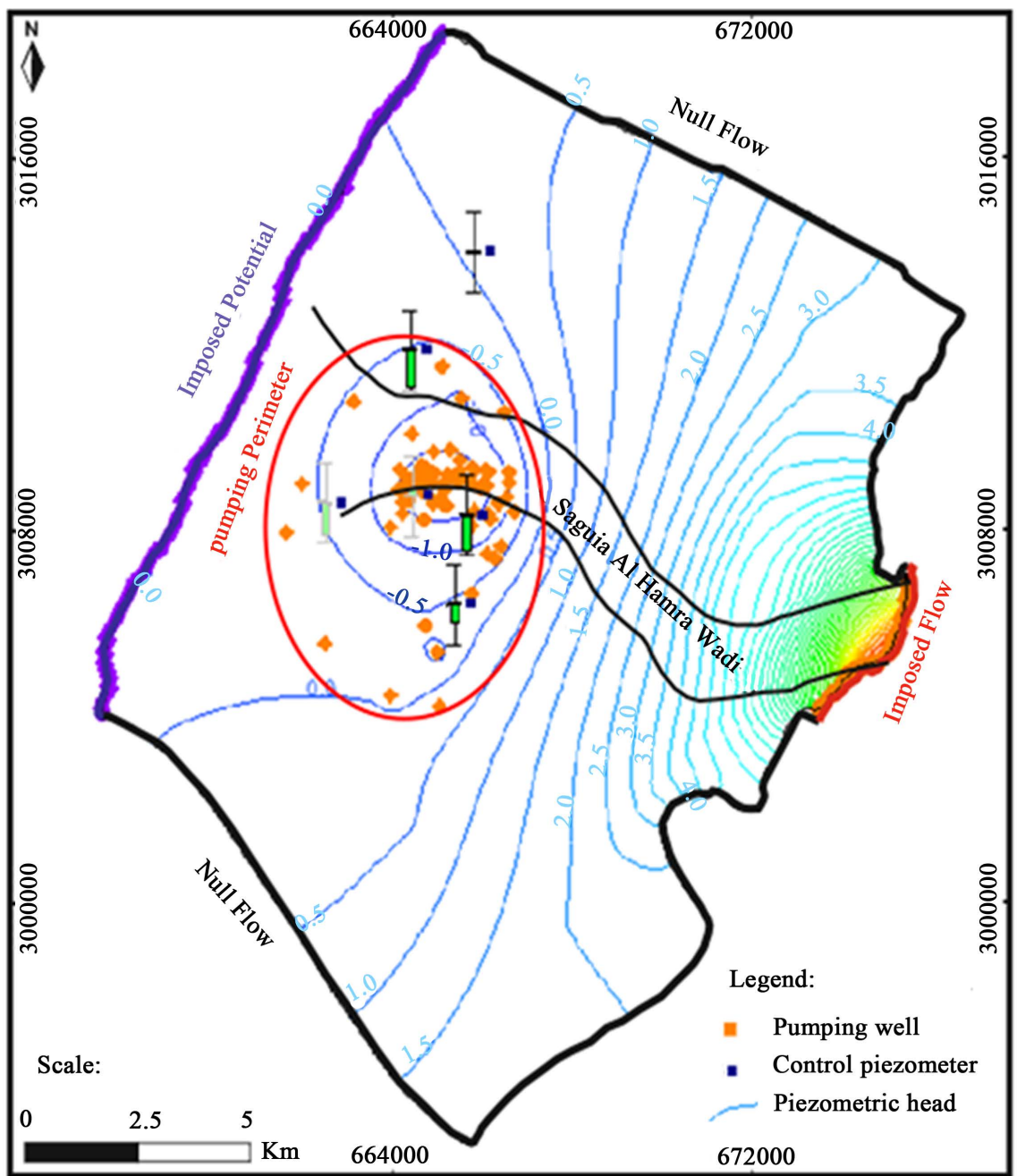

Figure 9. Fum Al Wad piezometry obtained by the calibration transient model in 2015 .

piezometers to calibrate the second hydrodynamic parameter (coefficient of storage); its value is selected carefully for better calibration which is about $10 \%$.

The results of this calibration are illustrated by six wells as in Figures 10-15. They show the evolution of the observed and simulated piezometric head by the transient model.

\section{2) Flow budget of the Fum Al Wad water-table}

The flow budget of the Fum Al Wad water-table has been obtained by simulation of the transient model during the period 1986-2015. The variations of the inflow and the outflow of this flow budget show a remarkable increase in the volume of the pumped water for the water-supply for drinking, agriculture and industry. This increase in pumping is accompanied with a decrease in the discharge of groundwater into the Atlantic Ocean. This indicates that the water-table is becoming increasingly deficient due to the intensive over-exploitation and the low recharge of the aquifer by rainwater infiltration. The calculated values by the transient model of this flow budget are illustrated in the following Figure 15. 


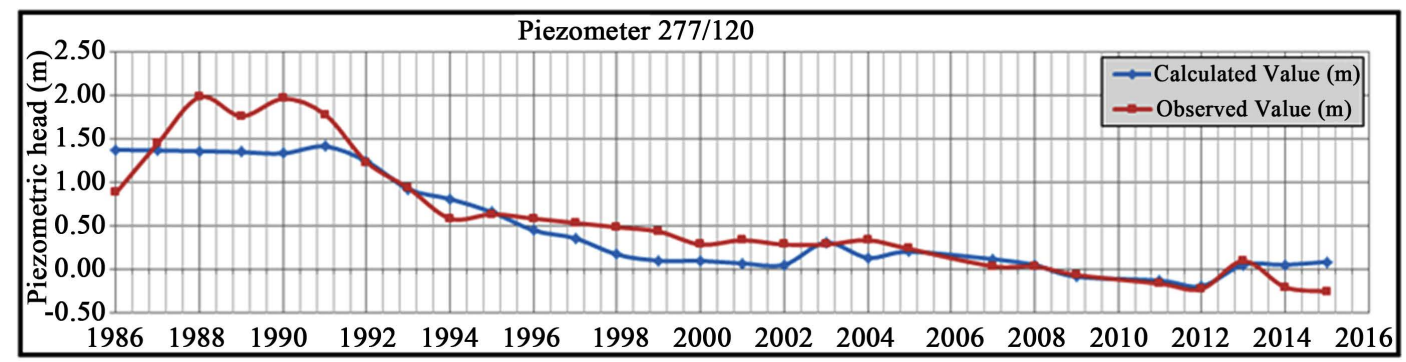

Figure 10. Calibration results of the observed and calculated head values by the transient model (Control piezometer 277/120).

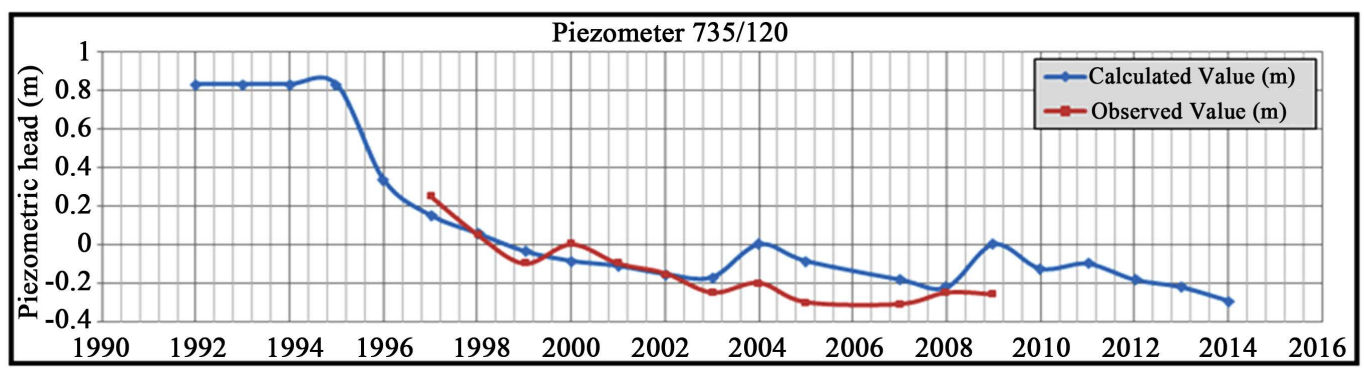

Figure 11. Calibration results of the observed and calculated head values by the transient model (Control piezometer 735/120).

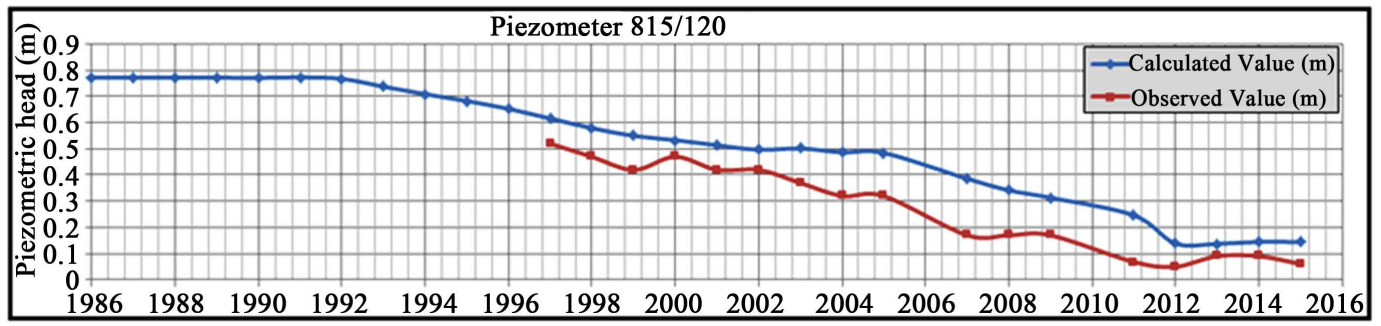

Figure 12. Calibration results of the observed and calculated head values by the transient model (Control piezometer 815/120).

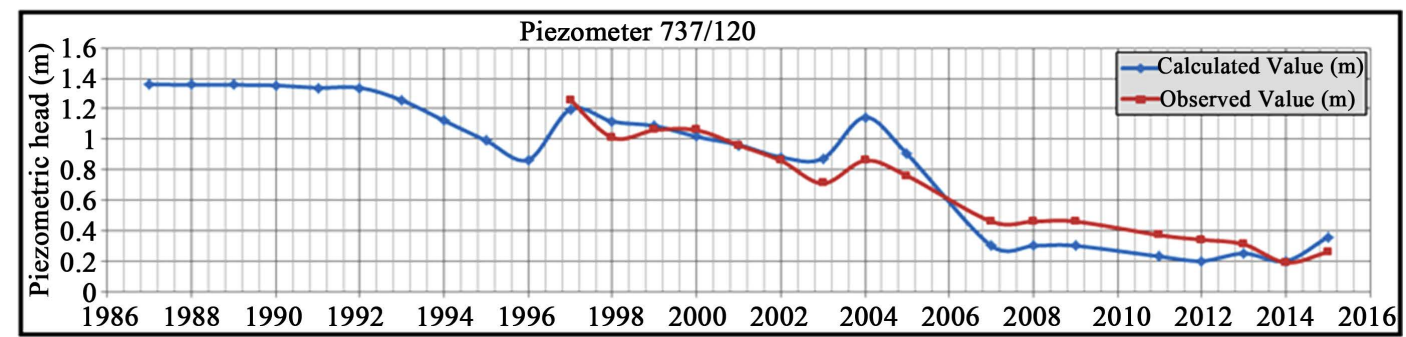

Figure 13. Calibration results of the observed and calculated head values by the transient model (Control piezometer 737/120).

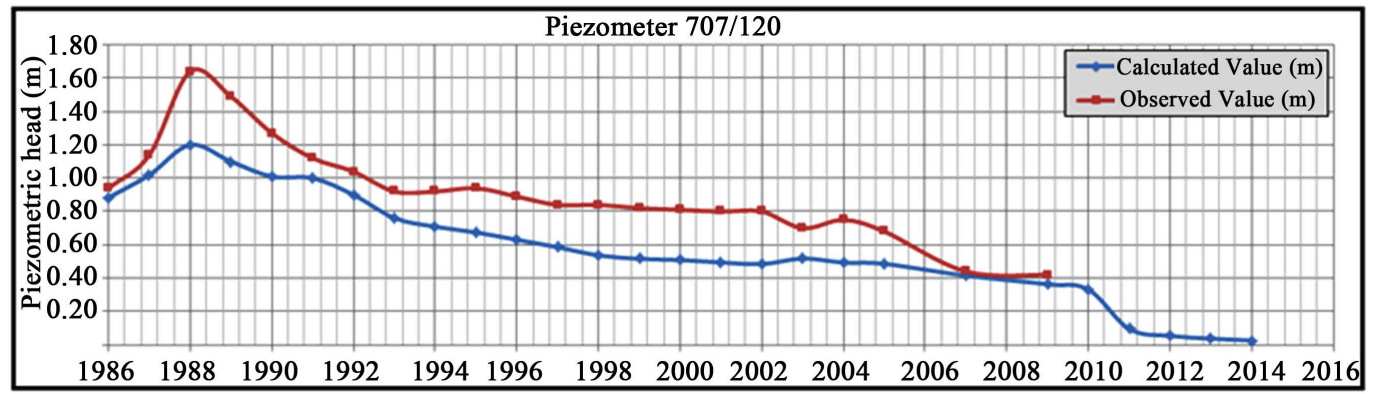

Figure 14. Calibration results of the observed and calculated head values by the transient model (Control piezometer 707/120). 


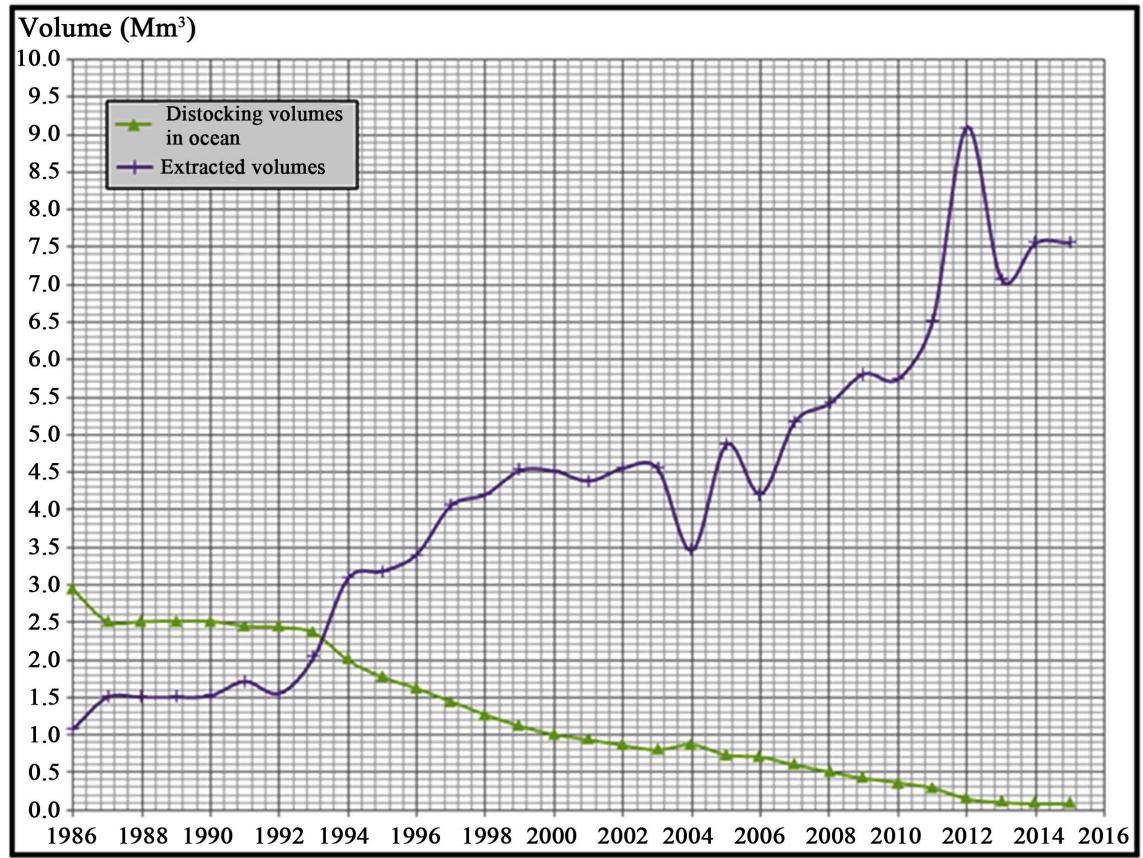

Figure 15. Variations of the flow budget of Fum Al Wad water-table calculated by transient regime during 1986-2015.

\section{3) The predicted results of the piezometric head for 2020 and 2030}

In order to perform the predicted piezometric simulations results of 2020 and 2030, we have used extracted volumes that refer to 2015, namely the ones utilized for water-supply. Furthermore, the data of the other volumes, related to agriculture and industry, are not used since they are absent from the available data.

The predicted piezometric head vision at the horizon of 2020 shows a piezometric depression which is about $2.4 \mathrm{~m}$ compared to 1986 piezometric data. In 2030, the Fum Al Wad water-table will experience a piezometric head decrease simulated by the prediction transient model which is about $2.5 \mathrm{~m}$ in comparison to 1986 piezometric data.

The following Figure 16 represents the predicted piezometric heads.

\subsection{Simulation of the Fum Al Wad Saltwater Intrusion in 2015}

The saltwater intrusion modeling of the Fum Al Wad water-table has elaborated annually throughout 29 years, which started from 1986 to 2015. The results obtained from the hydrodynamic transient model (see Figure 9) are retained for the new simulation of the saltwater intrusion in the water-table. The new databases used for this simulation are mainly: the freshwater density $(1 \mathrm{~g} / \mathrm{l})$ and the seawater density $(1.025 \mathrm{~g} / \mathrm{l})$. Thus, the hydrodispersifs parameters obtained by the calibration transient model of the saltwater intrusion are mainly: longitudinal and vertical dispersivity and molecular diffusion. Their values are retained successively: $5 \mathrm{~m}, 5 \mathrm{~m}$ and $10^{-9} \mathrm{~m}^{2} / \mathrm{s}$. Hence, the model has been initialized with a salinity condition on the coastal ocean which is $35 \mathrm{~g} / \mathrm{l}$. The effective porosity 


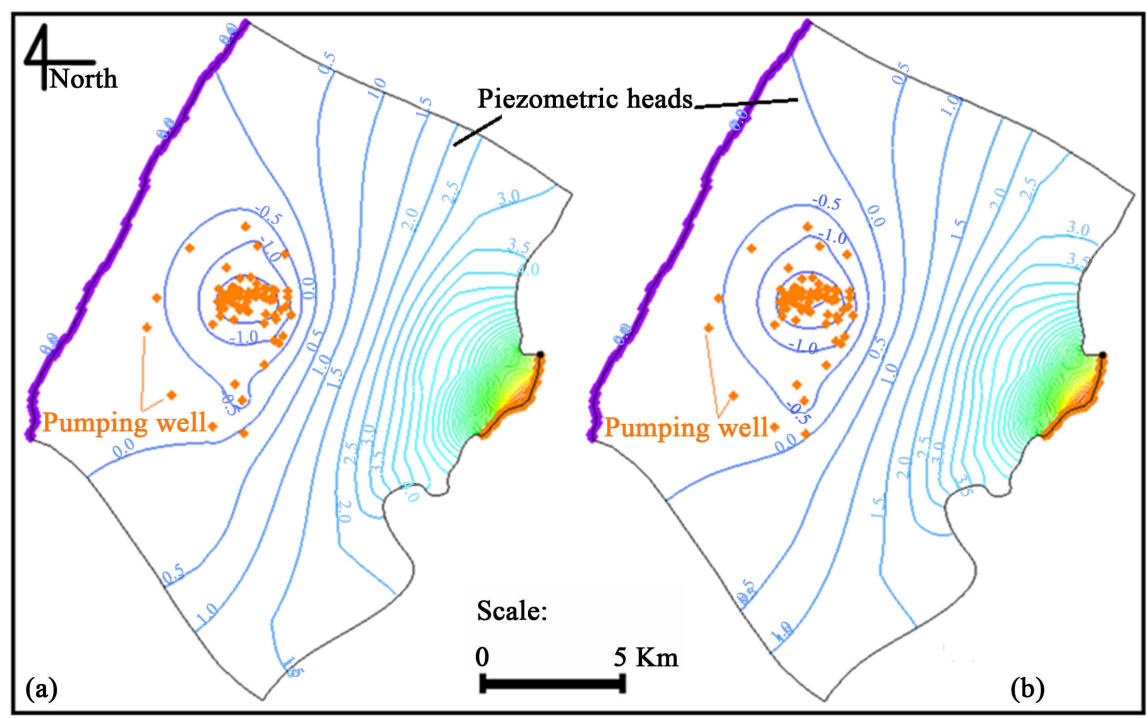

Figure 16. (a) The predicted piezometric heads of 2020; and (b) 2030 of Fum Al Wad water-table.

retained is $30 \%$; the density ratio is 1.5 (dimensionless). The Figure 17 below illustrates the results of saltwater intrusion that is obtained by SEAWAT-2000 simulation program in 2015.

The immigration of saltwater to the zone of pumping wells is usually caused by excessive water-extraction and the high permeability of sandy subsoil; the salt-wedge has advanced towards the pumping wells of the freshwater in Fum $\mathrm{Al}$ Wad aquifer with $4.3 \mathrm{~km}$ approximately, as it is illustrated in section B in Figure 16.

The calibration of the saltwater intrusion model has been done through five salinometers salinity data which are: 737/120,815/120,826/120, 1151/120 and 1156/120 (Table 1).

In order to perform the predicted salt-wedge simulations results of 2020 and 2030, we have used extracted volumes that refer to 2015, namely the ones utilized for water-supply. Furthermore, the data of the other volumes, related to agriculture and industry, are not used since they are absent from the available data.

The two predicted simulations of the years 2020 and 2030 are obtained by simulating saltwater intrusion in freshwater by the transient model. The Figure 16 shows the advancement of saltwater towards the pumping wells as it is illustrated in sections A, B and C in the West-East direction.

The results of saltwater-intrusion modeling found in 2015 in the Fum Al Wad aquifer has highlighted that the pumping wells located in less than $4.3 \mathrm{~km}$ from the Atlantic Ocean were contaminated by sea-water (see Figure 17 below).

Furthermore, the future modeling of saltwater intrusion has highlighted that the salt wedge has immigrated into the freshwater in pumping zone with $4.4 \mathrm{~km}$ approximately in 2020 and $4.7 \mathrm{~km}$ in 2030 . This indicates that the pumping wells will be partially contaminated. The following Figure 18 shows the state of salt 


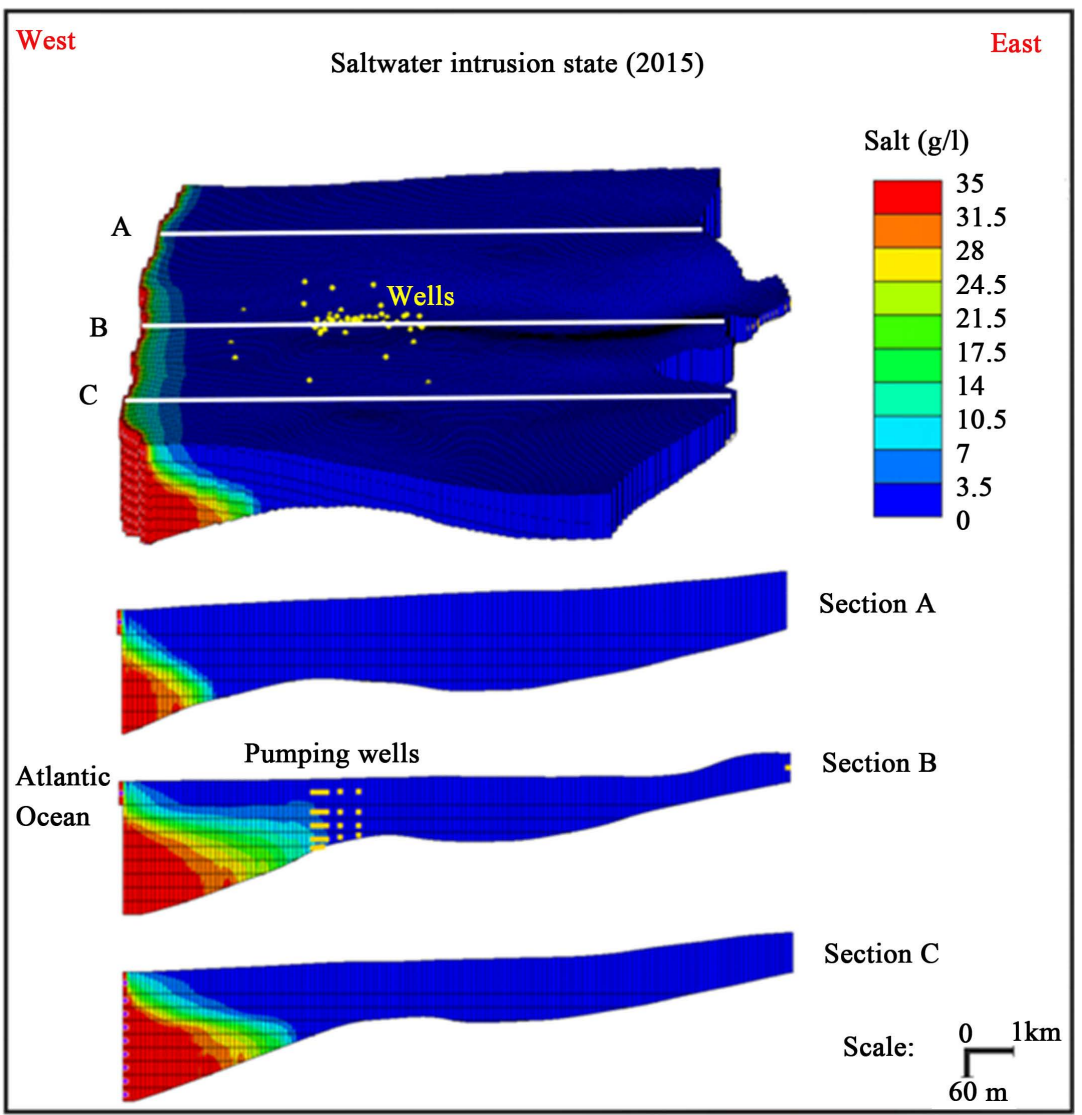

Figure 17. Salt-wedge in Fum Al Wad aquifer simulated by SEAWAT-2000 program in 2015.

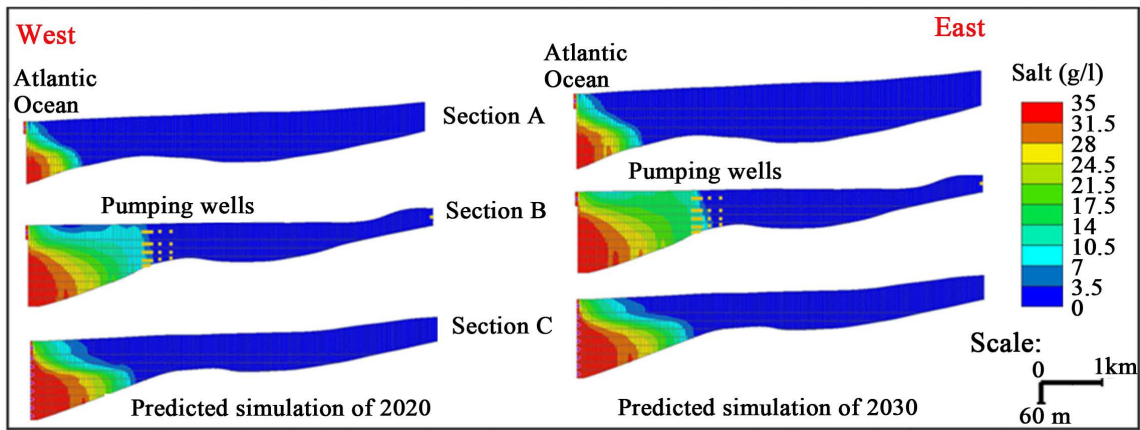

Figure 18. Cross sections of saltwater intrusion (salt wedge) in 2020 and 2030.

Table 1. The five salinometers to controlling salinity of the Fum Al Wad aquifer (the coordinate system is: WGS84 UTM zone 28 northing).

\begin{tabular}{ccccc}
\hline Name & X longitude & Y latitude & Elevation $(\mathrm{m})$ & Depth $(\mathrm{m})$ \\
\hline $737 / 120$ & 665,786 & $3,006,235$ & 21.36 & 100 \\
$815 / 120$ & 666,204 & $3,013,801$ & 12.97 & 102 \\
$826 / 120$ & 664,788 & $3,005,341$ & 20.95 & 102 \\
$1151 / 120$ & 665,328 & $3,008,527$ & 11 & 100 \\
$1156 / 120$ & 655,599 & $3,010,869$ & 16.6 & 104 \\
\hline
\end{tabular}


water intrusion in 2020 and 2030 in three sections A, B and C (right bank, Saquia Al Hamra Wadi bed, left bank) distributed over the study area.

\section{Discussion}

The conceptual model consists of the construction of the geometry of the Fum Al Wad aquifer, which is based on the use of a sufficient history of the lithological data of the boreholes, wells, piezometers and other geophysical (geoelectric, seismic) data. The initialization of the hydrogeological model of this aquifer was done by defining the boundary conditions: the null flux in North and South limits, the imposed flow around $0.18 \mathrm{~m}^{3} / \mathrm{s}$ in the East and the imposed potential $\mathrm{H}=$ $0 \mathrm{~m}$ in West (Atlantic Ocean).

Furthermore, the initial steady-state model was calibrated in 1986 using 40 observation piezometers. Thus, the main calibrated parameters are: the hydraulic conductivity, the effective porosity and the source and sink recharge rate (the Eastern limit).

The calibration of the transient model was done during a period of 29 years (1986-2015). The calibrated main parameter of the storage coefficient is done using 6 controlling piezometers with a complete piezometric history covering the entire simulation period of the transient model.

In addition, saltwater intrusion model of Fum $\mathrm{Al}$ Wad Aquifer was initiated by the same boundary conditions of the hydrodynamic model, except the western boundary which was defined as $35 \mathrm{~g} / \mathrm{l}$ of salinity concentration.

The model is calibrated with salinity data of the 5 salinometers (named: 737/120, $815 / 120,826 / 120,1151 / 120$ and 1156/120) which have a sufficient salinity history (1986-2015). They are located in the pumping wells zone of Fum Al Wad. However, the main hydrodispersive parameters (longitudinal and vertical dispersivity, molecular diffusion) are calibrated in a period of 29 years (1986-2015) taking into account the previous results obtained from hydrodynamic modeling in the steady-state and transient model.

In this work, the form of the freshwater-saltwater interface modeled by the SEAWAT-2000 program confirms the result of the geophysical study which explains the presence of the salt-wedge phenomenon in the pumping wells zone of Fum Al Wad Aquifer [41]. However, the salt-wedge moves diagonally from the West to the East with a gradual decrease in salinity concentration $(35 \mathrm{~g} / \mathrm{l})$ from the coast to the continent (pumping wells side).

The present study shows that this interface is not in natural equilibrium since its temporal-spatio evolution reflects advancement towards the continent; this occurs in parallel with the increase of the extraction volumes from the water-table and the decrease of the piezometric head. This situation is aggravated at the level of the extraction zone of the water-supply (National Office of Drinking Water) where the salinization goes up gradually at the local level.

The predicted simulations have shown that piezometry is always in a dynamic state in the extraction zone. This reflects that the piezometric head will decrease in 2020 and 2030 accompanied by the contamination of the pumping wells with 
seawater. This requires a quarterly artificial recharge rate with a necessary volume which is around $2 \mathrm{~m}^{3} / \mathrm{s}$ at the pumping zone.

By giving this critical situation, it is highly crucial to start acting so as to stop this serious trend and avoid the irreversible degradation of land. This requires raising farmers' awareness to use the new economical mode of drip irrigation with respect to groundwater resources.

The seawater desalination alternative which is already put in place by the Agency of Hydraulic Basin of the Sakia Al Hamra and Oued Eddahab (ABHSHOD), and it can be developed to reduce the impact of pumping wells on the salt-wedge.

The elaborated models in this work gave a preliminary vision of the qualitative and quantitative aspects of the Fum Al Wad water-table. These models require other recent hydrogeological data to cover the entire area of the aquifer in order to further improve the quality and credibility of the results in this work.

\section{Conclusions}

The Fum Al Wad aquifer represents an important reservoir for groundwater exploitation which is used for water supply, agriculture and industry. It supplies the Laayoun city, which has 217,732 citizens (2014 statistics), and it ensures the sustainability of the various economic activities in the region. This aquifer is located in a coastal area, west of the Laâyoune city; it extends on a surface of approximately $250 \mathrm{~km}^{2}$. Its limits are drawn based on facts and studies in the East and not identified in North and South. This resource belongs to a region with a Saharan climate where the average annual rainfall between 1993 and 2007 did not exceed a few tens of millimeters. Thus, the infiltration of rainwater is very low and insufficient for recharging the Fum Al Wad water-table.

The annual water volume subtracted from the aquifer during the period (1990-2015) according to the data from the National Office of Drinking Water is constantly growing and reached approximately $2.91 \mathrm{Mm}^{3}$ in 2015. This exploitation was accompanied by a gradual decline of the water-table and a considerable advancement of the salt-wedge.

The numerical modeling of the Fum Al Wad water-table has permitted to elaborate some piezometric maps which testify the recent evolution of the aquifer state. The piezometry obtained by the hydrodynamic transient model in 2015 marked a piezometric decrease at the pumping wells zone with about $2.3 \mathrm{~m}$, in comparison to the 1986 piezometric data. This is due to the increase of water-extraction rate for irrigation during the past 15 years. In addition, the calibration of the transient regime is carried out by using six piezometric controlling piezometers.

The simulated piezometry of 2015 should be verified with the measured piezometry in the study area to elaborate a new piezometric reference of that year. This operation could constitute a fundamental element for validating the mathematical model of the Fum Al Wad aquifer.

The flow budget calculated by the transient model during the 29 years (1986-2015) has showed an increase of the pumped volumes which reached $7.02 \mathrm{Mm}^{3}$ in 2015 . 
This increase in the volume of the pumped water is accompanied by a decrease of the outflow discharge in the Atlantic Ocean.

The numerical modeling of the saltwater intrusion has highlighted the lateral extension of the salt-wedge in the Fum Al Wad aquifer. The simulated results showed the location of the interface between saltwater and freshwater, as in section B of the transient model in 2015 (Figure 17), with $4.3 \mathrm{~km}$ approximately at the level of the pumping zone.

The results of the simulated scenarios for the years 2020 and 2030 helped in predicting the future states of the piezometric head and of the saltwater intrusion in Fum Al Wad water-table. In this respect, the predicted results showed that the piezometric values decrease successively 2.4 and $2.5 \mathrm{~m}$ in 2020 and 2030. This decrease of the piezometric head, which is due to the over-exploitation of groundwater, will accompany an advancement of the salt-wedge, with $4.4 \mathrm{~km}$ in 2020 and $4.7 \mathrm{~km}$ in 2030, towards the freshwater in the pumping zone of Fum Al Wad aquifer (Sections B in Figure 18).

\section{Acknowledgements}

We would like to thank the Agency of Hydraulic Basin of the Sakia El Hamra and Oued Eddahab, the Minister of Energy, Mine Water and Environment-Rabat and AFRICA GEO-SERVICES society who provided us with the necessary database for the fulfillment of this study.

\section{References}

[1] Gaaloul, N. (2011) Water Resources and Management in Tunisia. International Journal of Water, 6, 92-116.

[2] Bear, J., Cheng, A.H.D., Sorek, S., Herrera, I. and Ouazar, D. (1999) Seawater Intrusion in Coastal Aquifers. Kluwer Academic Publishers, Dordrecht, 625 p.

[3] Chatelier, N.C. and Surdyk, N. (2011) Sea Level Rise Induced by Climate Change: Consequences on Saline Intrusion in the Coastal Aquifers of Metropolitan France. BRGM Report.

[4] Comte, J.C. (2008) Contribution of Electrical Tomography to the Modeling of Densities in Coastal Aquifers. PhD Thesis, University of Avignon and Pays de Vaucluse, Avignon.

[5] Priyanka, B.N. and Mohan Kumar, M.S. (2017) Direct and Inverse Modeling of Seawater Intrusion: A Perspective. Journal Geological Society of India, 90, 595-601. https://doi.org/10.1007/s12594-017-0757-x

[6] Colombani, N. and Mastrocicco, M. (2017) Modelling the Salinization of a Coastal Lagoon-Aquifer System. IOP Conference Series Earth and Environmental Science, 82, Article ID: 012003. https://doi.org/10.1088/1755-1315/82/1/012003

[7] Gopinath, S., Srinivasamoorthy, S., Saravanan, K., Suma, K., Prakash, C.S., Senthilnathan, R., Chandrasekaran, D., Srinivas, N., Sriniva, Y. and Sarma, V.S. (2016) Modeling Saline Water Intrusion in Nagapattinam Coastal Aquifers, Tamilnadu, India. Modeling Earth Systems and Environment, 2, 2. https://www.researchgate.net/publication/286477701

[8] Lathashri, U.A. and Mahesha, A. (2015) Simulation of Saltwater Intrusion in a Coastal Aquifer in Karnataka, India. International Conference on Water Resources, 
Coastal and Ocean Engineering, Mangalore, 12-14 March 2015, 700-705.

http://creativecommons.org/licenses/by-nc-nd/4.0/

[9] Zexuan, X., Bill, X.H. and Ming, Y. (2017) Numerical Modeling and Sensitivity Analysis of Seawater Intrusion in a Dual-Permeability Coastal Karst Aquifer with Conduit Networks. Hydrology and Earth System Sciences, 22, 221-239, https://doi.org/10.5194/hess-2017-85

[10] Idris, A.N., Aris, A.Z., Narany, T.S., Mangala, S.P., Suratman, S., Tawnie, I., Shamsuddin, M.K.N. and Sefie, A. (2017) Simulation of Saltwater Intrusion in Coastal Aquifer of Kg. Salang, Tioman Island, Pahang, Malaysia. MATEC Web of Conferences, 103, Article No. 04024. https://doi.org/10.1051/matecconf/201710304024

[11] Thomas, A., Eldho, T.I. and Rastogi, A.K. (2016) Simulation of Seawater Intrusion in Coastal Confined Aquifer Using a Point Collocation Method Based Meshfree Model. Journal of Water Resource and Protection, 8, 534-549.

http://www.scirp.org/journal/jwarp https://doi.org/10.4236/jwarp.2016.84045

[12] Noorabadi, S., Sadraddini, A.A., Nazemi, A.H. and Delirhasannia, R. (2017) Laboratory and Numerical Investigation of Saltwater Intrusion into Aquifers. Journal of Materials and Environmental Sciences, 8, 4273-4283.

http://www.jmaterenvironsci.com/

[13] Hanasaki, N., Yoshikawa, S., Kakinuma, K. and Kanae, S. (2016) A Seawater Desalination Scheme for Global Hydrological Models. Hydrology and Earth System Sciences, 20, 4143-4157. http://www.hydrol-earth-syst-sci.net/20/4143/2016/ https://doi.org/10.5194/hess-20-4143-2016

[14] Frissant, N., René-Crail, C., Bonnier, J. and De La Torre, Y. (2005) The Phenomenon of Saline Intrusion in Réunion: State of Knowledge and Synthesis of Available Data. Report BRGM/RP-54330-FR.

[15] Christian, D., Langevin1, W., Shoemaker1, B. and Weixing, G. (2003) MODFLOW-2000, the U.S. Geological Survey Modular Ground-Water Model-Documentation of the SEAWAT-2000 Version with the Variable-Density Flow Process (VDF) and the Integrated MT3DMS Transport Process (IMT). U.S. Geological Survey Open-File Report 03-426.

[16] Arfib, B., Cavalera, T. and Gilli, E. (2006) Influence of Hydrodynamics on the Saltwater Intrusion in Coastal Karstic Aquifer. C. R. Geoscience, 338, 757-767. https://doi.org/10.1016/j.crte.2006.07.001

[17] Bear, J. (1979) Hydraulics of Groundwater. Mac Graw-Hill, Inc., New York, 568 p.

[18] Kashef, A.I. (1983) Harmonizing Ghyben-Herzberg Interface with Rigourous Solutions. Ground Water, 21, 153-159.

[19] Barlow Paul, M. (2003) Ground Water in Freshwater-Saltwater Environments of the Atlantic Coast.

[20] ABHSHOD (Hydraulic Basin Agency of the Sakia El Hamra and Wadi Eddahab) (2010) Inventory of the Pumping Groundwater in the Basin of Sakia El Hamra and Wad Eddahab.

[21] DRHS (Regional Direction of Sahara Hydraulic) (2003) Geophysical Survey by Electrical Soundings, by Nuclear Magnetic Resonance Soundings and by Seismic in the Laayoun-Dakhla Sedimentary Basin.

[22] Dillon, R. and Soujy, J. (1974) Geology of West Africa and Canary and Cape Verde Islands. In: Nairn, A.E.M. and Stehli, F.G., Eds., The Ocean Basins and Margin, Volume 2: The North Atlantic, Plenum Press, New York, 315-390.

https://doi.org/10.1007/978-1-4684-3033-2_10 
[23] Lehner, P. and De Ruiter, P.A.D. (1977) Structural History of the Atlantic Margin of Africa. Bulletin-American Association of Petroleum Geologists, 61, 961-981.

[24] Alia, M. (1945) Caracteristicas morphograficas y geologicas de la zona septentrional del sahara espanol.

[25] Alia, M. (1945) El Quaternario en el Sahara espanol. 149-163.

[26] Choubert, G. and Ambroggi, R. (1953) Preliminary Note on the Presence of Two Sedimentary Cycles in the Marine Pliocene of Morocco. Notes Serv. Geol. Morocco, t. 7Mem., No. 117, 5-53.

[27] Choubert, G., Faure Muret, A. and Hottinger, L. (1966) Geological Survey of the Coastal Basin of Tarfaya. Notes et memoires du service geologique No 175 Tome I, stratigraphie, 7-106.

[28] Lecointre, G. (1952) Research on the Neogene and the Quaternary Marine of the Atlantic Coast of Morocco. Notes and Mem. Serv. Geol. Morocco, No. 174, t. III.

[29] Lecointre, G. (1963) Note on the Marine Neogene and Quaternary of the Spanish Sahara (Seguia el Hamra and Rio the Oro). Notas Com. Inst. geol. minero Esp., No. 71.

[30] Lecointre, G. (1965) A Hypothesis on the Age of Quaternary Transgression in Mauritania. Notes and Mem. Serv. Geol. Morocco., t. 25, No. 185, 79-80.

[31] Lecointre, G. (1966) Neogene and Quaternary of the Tarfaya Coastal Basin. Notes and Mem. Serv. Geol. Morocco., No. 175, 255-288.

[32] Martinis, B. and Visintin, V. (1966) Geological Datas on the Coastal Sedimentary Basin of Tarfaya (Southern Morocco). In: Reyre, D., Ed., Sedimentary Basins of the African Coast, Part 1 (Atlantic Coast), Ass Afr Geol Surv, UNESCO, 13-26.

[33] Ratschiller, L.K. (1970) Lithostratigraphy of the Northern Spanisch Sahara. Mem. Mus. Trid. Sc. Nat trento, Vol. 18, fasc. 1, 9-78.

[34] MEM (Ministry of Energy and Mines) (2002) Geological Map to 1000000th. Paper of Laayoun.

[35] Harbaugh, A.W., Banta, E.R., Hill, M.C. and McDonald, M.G. (2000) MODFLOW-2000, the U.S. Geological Survey Modular Ground-Water Model-User Guide to Modularization Concepts and the Ground-Water Flow Process. U.S. Geological Survey Open-File Report 00-92, 121 p.

[36] Zheng, C. (2006) MT3DMS v5.2 Supplemental User's Guide. Technical Report to the U.S. Army Engineer Research and Development Center, Department of Geological Sciences, University of Alabama, Tuscaloosa, $24 \mathrm{p}$.

[37] Zheng, C. and Wang, P.P. (1999) MT3DMS, A Modular Three-Dimensional Multi-Species Transport Model for Simulation of Advection, Dispersion and Chemical Reactions of Contaminants in Groundwater Systems; Documentation and User's Guide. U.S. Army Engineer Research and Development Center Contract. Report SERDP-99-1, Vicksburg, 202 p.

[38] Guo, W. and Langevin, C.D. (2002) User's Guide to SEAWAT: A Computer Program for Simulation of Three-Dimensional Variable-Density Ground-Water Flow: U.S. Geological Survey Techniques of Water-Resources Investigations. Book 6, Chap. A7, 77 p.

[39] Bear, J. and Bachmat, Y. (1991) Introduction to Modeling of Transport Pheno-Mena in Porous Media. Kluwer Academic Publishers, Dordrecht.

[40] DRHS (Regional Direction of Sahara Hydraulic) (2005) Modeling Study of the Fum Al Wad Aquifer-Laayoun Region, Morocco. 
[41] El Mokhtar, M., Chibout, M., El Kanti, S.M., El Mansouri, B., Benslimane, A. and Faqihi, F.-Z. (2016) Application of Geophysical Methods to the Determination of the Hydrogeological Situation of the Saline Intrusion at the Sensing Field of the Fum Al Wad Coastal Aquifer, Province of Laayoun, Morocco. Journal of Geomaghreb, 12, 1-11. 